\title{
Unraveling the variability and genetic structure of barker frog Physalaemus cuvieri (Leiuperinae) populations from different regions of Brazil
}

\author{
M. Conte ${ }^{1,2}$, C.P. Targueta ${ }^{1}$, M.I. Zucchi ${ }^{3}$, A.P. Souza ${ }^{2}$ and \\ S.M. Recco-Pimentel ${ }^{1}$ \\ ${ }^{1}$ Departamento de Biologia Estrutural e Funcional, Instituto de Biologia, \\ Universidade Estadual de Campinas, Campinas, SP, Brasil \\ ${ }^{2}$ Departamento de Biologia Vegetal, Instituto de Biologia, \\ Universidade Estadual de Campinas, Campinas, SP, Brasil \\ ${ }^{3}$ Polo Regional Centro Sul, Agência Paulista de Tecnologia dos Agronegócios, \\ Piracicaba, SP, Brasil \\ Corresponding author: S.M.R. Pimentel \\ E-mail: shirlei@unicamp.br
}

Genet. Mol. Res. 13 (3): 8055-8065 (2014)

Received March 26, 2013

Accepted July 29, 2013

Published February 21, 2014

DOI http://dx.doi.org/10.4238/2014.February.21.4

\begin{abstract}
The barker frog Physalaemus cuvieri is widely distributed in South America and is found in all regions of Brazil. Significant intraspecific morphological variation in this species has been reported. To determine the genetic structure of the natural Brazilian populations of $P$. cuvieri, 10 different populations geographically separated by 99.41 to $2936.75 \mathrm{~km}$ were evaluated using 10 polymorphic microsatellite loci. In addition, mitochondrial DNA data were analyzed to determine genetic distance between the populations. The genetic variation was found to be significant in most of the populations $\left(H_{\mathrm{E}}\right.$ ranged from 0.40 to 0.59 , and allelic richness ranged from 2.07 to 3.54). An $F_{\mathrm{ST}}$ value of 0.27 indicated that high genetic structure was present among the $P$. cuvieri populations. STRUCTURE
\end{abstract}


analyses grouped the 10 populations into nine clusters and indicated that only two of the populations were not genetically differentiated. The genetic distance calculated from the mitochondrial DNA data showed values $<0.03$ for seven of the populations.

Key words: Physalaemus; Barker frog; Population structure; Microsatellite; Mitochondrial DNA

\section{INTRODUCTION}

Physalaemus was recently included in the subfamily Leiuperinae (Pyron and Wiens, 2011). Currently, there are 45 species in this genus, and they are widely distributed throughout South America. The Physalaemus cuvieri group (sensu Nascimento et al., 2005) is composed of the following species: P. albonotatus, P. centralis, P. cicada, P. cuqui, P. cuvieri, P. ephippifer, P. erikae, P. fischeri, and P. kroyeri (Frost, 2013).

P. cuvieri is found in all regions of Brazil, the Misiones Province of Argentina, eastern Paraguay, the departments of Beni and Santa Cruz in Bolivia and, possibly, the lowlands of southern Venezuela (Frost, 2013). In Brazil, P. cuvieri inhabits a large area (Global Amphibian Assessment, 2009). It has been reported that significant intraspecific morphological variations, including size, the presence of warts on the skin, finger size and the presence of an inner tarsal tubercle and inguinal and parotoid glands, exist in the species (Nascimento et al., 2005). Distinct breeding periods in P. cuvieri populations in the northeastern and southeastern regions of Brazil have also been found (Barreto and Andrade, 1995).

The P. cuvieri group contains closely related species that also demonstrate intraspecific morphological variation, and these related species have been considered to be sibling species of P. albonotatus and P. centralis (Barrio, 1965; Frost, 2013). Therefore, the identification of a species based exclusively on morphological characteristics is not reliable (Barrio, 1965). Although new species are known to emerge, their identification is often difficult.

Previous groups have investigated $P$. cuvieri populations. Random amplified polymorphic DNA markers have been used to reveal complex spatial variation in P. cuvieri populations from the Cerrado region of the State of Goiás, Brazil, which consists of significant spatial heterogeneity coupled with low genetic distance similarity (Telles et al., 2006). In addition, cytogenetic studies have found chromosomal variation at both the intra- and interpopulation level for the number and localization of nucleolar organizer regions in P. cuvieri (Silva et al., 1999; Quinderé et al., 2009). Lastly, microsatellite markers have been used to assess the genetic structure of closely related species within the P. cuvieri group (Conte et al., 2011). Although previous studies have found evidence of genetic diversity between $P$. cuvieri populations, microsatellite studies, including those determining the genetic structure of $P$. cuvieri populations, have not been reported in the literature.

Ten polymorphic microsatellite loci from a GA-CA-enriched library have been isolated from P. cuvieri (Conte et al., 2009). These loci have enabled studies on the genetic structure of the populations of this species. In the present study, we used these polymorphic microsatellite loci to assess the genetic diversity and genetic structure of 10 P. cuvieri populations from various regions of Brazil. The populations were separated geographically by 99.41 to $2936.75 \mathrm{~km}$, and their mitochondrial DNA was examined. This study aimed to contribute to our knowledge of this anuran species. 


\section{MATERIAL AND METHODS}

\section{Population sampling and DNA extraction}

P. cuvieri specimens ( $\mathrm{N}=160$ adults) were sampled from 10 locations in Brazil at distances ranging from 99.41 to $2936.75 \mathrm{~km}$ (Figure 1 and Table 1). Specimens were collected in the summer seasons from 1999 to 2007 . The 10 populations were chosen to represent multiple Brazilian regions, including those known to exhibit cytogenetic variation. The abbreviations used are as follows: MA1 = São Pedro da Água Branca, Maranhão; MA2 = Urbano Santos, Maranhão; TO3 = Porto Nacional, Tocantins; MG4 = Uberlândia, Minas Gerais; SP5 = Vitória Brasil, São Paulo; SP6 = Palestina, São Paulo; SP7 = Nova Itapirema, São Paulo; MT8 = Chapada dos Guimarães, Mato Grosso; BA9 = Vitória da Conquista, Bahia; and RS10 = Passo Fundo, Rio Grande do Sul. Genomic DNA from tissue samples (liver, heart and/or muscle) was extracted using the Genomic Prep Cells and Tissues DNA Isolation kit (Amersham Pharmacia Biotech, USA) by the Tris, NaCl, EDTA, and SDS method (Martins and Bacci Jr., 2001).

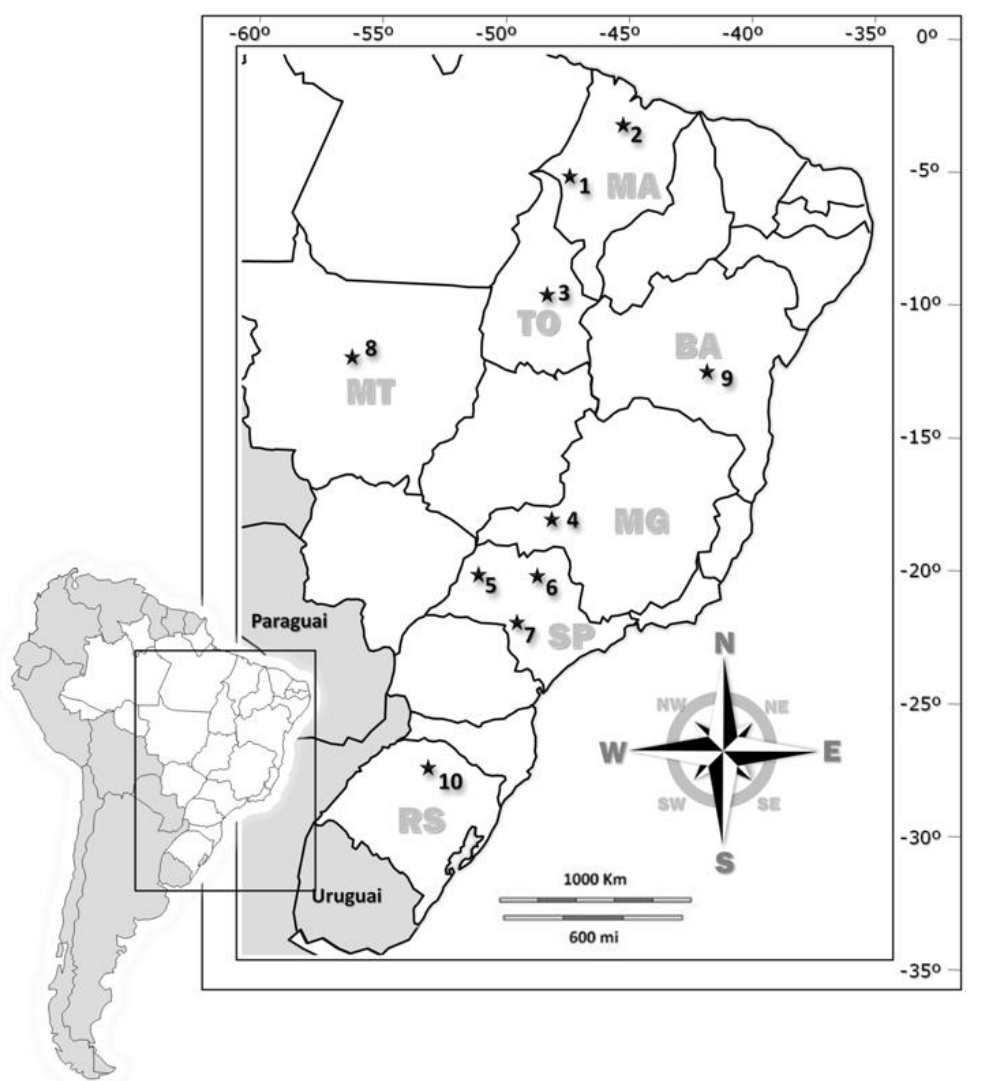

Figure 1. Map of Brazil displaying the ten locations in which natural populations of Physalaemus cuvieri were surveyed. MA1 = São Pedro da Água Branca, MA; MA2 = Urbano Santos, MA; TO3 = Porto Nacional, TO; MG4 = Uberlândia, MG; SP5 = Vitória Brasil, SP; SP6 = Palestina, SP; SP7 = Nova Itapirema, SP; MT8 = Chapada dos Guimarães, MT; BA9 = Vitória da Conquista, BA; and RS10 = Passo Fundo, RS. 


\section{Microsatellite analysis}

Ten previously identified $P$. cuvieri microsatellite loci were used for genetic analyses of $P$. cuvieri populations (Conte et al., 2009) and included the following: P1A10, P3A12, P6A8, P9C1, P12D1, P13A5, P17B10, P20D4, P21D10, and P22C9. The PCR products were visualized on $3 \%$ agarose gels, and DNA amplification products were separated by electrophoresis on $6 \%$ denatured polyacrylamide gels and silver stained (Creste et al., 2001). DNA fragment sizes were determined by comparison with a 10-bp DNA ladder (Invitrogen, USA).

\section{Mitochondrial DNA sequencing}

The mitochondrial $16 \mathrm{~S}$ ribosomal gene was chosen as a region of conserved sequence. The 16S gene was amplified from the samples using the following primers: 12SL13, Titus I (H), Hedges 16L2a, Hedges16H10, 16Sar-L, and 16Sbr-H (for primer sequences, see Goebel et al., 1999). The PCR amplified products were purified with a GFX PCR and Gel Band DNA Purification kit (GE Healthcare, England) and used directly as the template for sequencing. Sequencing was performed in an automatic ABI/Prism DNA sequencer (Applied Biosystems, Foster City, CA, USA) using the BigDye Terminator kit (Applied Biosystems) according to manufacturer instructions. DNA sequences were bidirectionally sequenced and edited using the Bioedit version 7.0.1 software (http://www.mbio.ncsu.edu/BioEdit/bioedit.html) and aligned using ClustalW.

\section{Data analysis}

Expected $\left(H_{\mathrm{E}}\right)$ and observed $\left(H_{\mathrm{O}}\right)$ heterozygosities and private alleles were estimated using the genetic data analysis (Lewis and Zaykin, 2000). The FSTAT software (Goudet, 1995) was used to estimate pairwise $F_{\mathrm{ST}}$ among the populations through Nei's F-statistics. The Weir and Cockerham estimator of $F_{\text {IS }}(f$ - inbreeding coefficient) was used to investigate possible deviations from Hardy-Weinberg equilibrium and to determine the mean of allelic richness. Genetic differentiation among populations was estimated using the $F_{\mathrm{ST}}$ statistic (Wright, 1951).

Clustering of the P. cuvieri populations was performed using the STRUCTURE software (Pritchard et al., 2000). The settings used were as follows: a burn-in length of 100,000, MCMC repeats of 100,000 and 10 iterations for each $\mathrm{K}$. The possible Ks ranged from 2 to 10. A distinct cluster number (K) was identified (Evanno et al., 2005). This number examines the second order rate of change of the log probability of the data with respect to the number of clusters.

The Geographic Distance Matrix Generator (Ersts, 2007) was used to calculate all pairwise distances among the 10 populations from a list of geographic coordinates.

The genetic distance between the 10 populations of $P$. cuvieri was determined using mitochondrial DNA sequences from two specimens from the MA1 and MT8 populations and three specimens from the remaining eight populations. In total, 28 sequences were assessed using MEGA version 4 (Tamura et al., 2007). The sequences of the following four Physalaemus species were obtained from GenBank and used as outgroups: P. gracilis (Frost et al., 2006), P. nattereri, P. barrioi, and P. signifier (Ron et al., 2006). 


\section{RESULTS}

\section{Microsatellite data analysis}

The $H_{\mathrm{E}}$ per $P$. cuvieri population ranged from 0.402 in SP7 to 0.597 in RS10. The $H_{\mathrm{O}}$ per population ranged from 0.417 in TO3 to 0.803 in MA1. Allelic richness varied from 2.070 to 3.543 (Table 1). The overall inbreeding coefficient was $f=-0.11(95 \% \mathrm{CI})$. The dominance of negative $f$ values per population (Table 1) revealed an excess of heterozygotes. This finding might have been due to favorable heterozygote selection during sampling and may indicate an absence of inbreeding. Private alleles were present in two loci from the RS10 population and in one locus from the SP5 population.

Table 1. Physalaemus cuvieri populations, the sampling locations in Brazil and the specimen identification numbers.

\begin{tabular}{|c|c|c|c|c|c|c|c|c|}
\hline $\begin{array}{l}\text { Sampling location/ } \\
\text { Latitude/Longitude }\end{array}$ & $\begin{array}{l}\text { Sample } \\
\text { size }\end{array}$ & Region & Voucher accession No. & Population & $H_{\mathrm{o}}$ & $H_{\mathrm{E}}$ & $f$ & $\begin{array}{l}\text { Allelic } \\
\text { richness }\end{array}$ \\
\hline $\begin{array}{l}\text { São Pedro da Água Branca, } \\
\text { MA } 5^{\circ} 00^{\prime} 02.85^{\prime \prime} \mathrm{S}, 48^{\circ} 17^{\prime} 26.97^{\prime \prime} \mathrm{W}\end{array}$ & 13 & Northeast & $\begin{array}{l}\text { MNRJ } 24233, \text { MNRJ } 24234, \text { MNRJ } 24255 \\
\text { to MNRJ } 24261 \text { and MNRJ } 24263 \text { to } 24266\end{array}$ & MA1 & 0.803 & 0.481 & -0.720 & 2.263 \\
\hline $\begin{array}{l}\text { Urbano Santos, MA } 3^{\circ} 12^{\prime} 30.07^{\prime \prime S} \text {, } \\
43^{\circ} 24^{\prime} 16.27^{\prime \prime W}\end{array}$ & 15 & Northeast & $\begin{array}{l}\text { ZUEC } 13091,13095,13097,13098 \\
13102,13104,13105,13106,13107 \\
13108,13110,13111,13124,13126 \\
13127\end{array}$ & MA2 & 0.569 & 0.435 & -0.322 & 2.707 \\
\hline $\begin{array}{l}\text { Porto Nacional, TO } 10^{\circ} 42^{\prime} 27.90^{\prime \prime} \mathrm{S} \text {, } \\
48^{\circ} 25^{\prime} 01.35^{\prime \prime} \mathrm{W}\end{array}$ & 21 & North & $\begin{array}{l}\text { ZUEC } 13374,13376 \text { to } 13379 \text {, } \\
13355 \text { to } 13359,14691 \text { to } 14697 \text {, } \\
14699 \text { to } 14702\end{array}$ & TO3 & 0.417 & 0.571 & 0.273 & 3.543 \\
\hline $\begin{array}{l}\text { Uberlândia, MG } 18^{\circ} 54^{\prime} 39.99^{\prime \prime S} \text {, } \\
48^{\circ} 20^{\prime} 25.76^{\prime \prime} \mathrm{W}\end{array}$ & 16 & Southeast & $\begin{array}{l}\text { ZUEC } 13366 \text { to } 13372 \text {, } \\
14705 \text { to } 14713\end{array}$ & MG4 & 0.505 & 0.484 & -0.046 & 2.974 \\
\hline $\begin{array}{l}\text { Vitória Brasil, SP } 20^{\circ} 11^{\prime} 49.65^{\prime \prime S}, \\
50^{\circ} 29^{\prime} 22.82^{\prime \prime} \mathrm{W}\end{array}$ & 14 & Southeast & ZUEC 14667 to 14680 & SP5 & 0.508 & 0.543 & 0.064 & 2.920 \\
\hline $\begin{array}{l}\text { Palestina, SP } 20^{\circ} 23^{\prime} 29.69^{\prime \prime} \text {, } \\
49^{\circ} 25^{\prime} 5806^{\prime \prime} \mathrm{W}\end{array}$ & 17 & Southeast & $\begin{array}{l}\text { ZUEC } 14634 \text { to } 14642 \text {, } \\
14730 \text { to } 14732,14643 \text { to } 14647\end{array}$ & SP6 & 0.502 & 0.420 & -0.200 & 2.583 \\
\hline $\begin{array}{l}\text { Nova Itapirema, SP } 21^{\circ} 06^{\prime} 00.12^{\prime S} \text {, } \\
49^{\circ} 31^{\prime} 59.92^{\prime \prime} \mathrm{W}\end{array}$ & 12 & Southeast & $\begin{array}{l}\text { ZUEC } 12355 \text { to } 12357 \\
14681 \text { to } 14689\end{array}$ & SP7 & 0.616 & 0.402 & -0.571 & 2.070 \\
\hline $\begin{array}{l}\text { Chapada dos Guimarães, } \\
\text { MT } 15^{\circ} 27^{\prime} 10.24^{\prime \prime S}, 55^{\circ} 44^{\prime} 20.94^{\prime \prime} \mathrm{W}\end{array}$ & 17 & $\begin{array}{l}\text { Middle } \\
\text { West }\end{array}$ & $\begin{array}{l}\text { ZUEC } 14616,14617 \text {, } \\
14619 \text { to } 14633\end{array}$ & MT8 & 0.441 & 0.480 & 0.080 & 2.905 \\
\hline $\begin{array}{l}\text { Vitória da Conquista, BA } \\
14^{\circ} 51^{\prime} 53.12^{\prime \prime} \mathrm{S}, 40^{\circ} 50^{\prime} 05.82^{\prime \prime} \mathrm{W}\end{array}$ & 16 & Northeast & ZUEC 14714 to 14729 & BA9 & 0.462 & 0.512 & 0.100 & 2.960 \\
\hline $\begin{array}{l}\text { Passo Fundo, RS } \\
28^{\circ} 13^{\prime} 35.90^{\prime \prime S}, 52^{\circ} 28^{\prime} 42.71^{\prime \prime} \mathrm{W}\end{array}$ & 19 & South & ZUEC 14648 to 14666 & RS10 & 0.634 & 0.597 & -0.063 & 3.327 \\
\hline
\end{tabular}

$\mathrm{MA}=$ Maranhão; $\mathrm{TO}=$ Tocantins; $\mathrm{MG}=$ Minas Gerais; $\mathrm{SP}=$ São Paulo; $\mathrm{MT}=$ Mato Grosso; $\mathrm{BA}=$ Bahia; $\mathrm{RS}=$ Rio Grande do Sul; ZUEC = Zoology Museum (Prof. Dr. Adão José Cardoso), Universidade Estadual de Campinas, SP, Brazil; MNRJ = Museu Nacional do Rio de Janeiro, Universidade Federal do Rio de Janeiro, SP, Brazil; and BC= Laboratory register number in the Department of Anatomy, Cell Biology and Physiology, Universidade Estadual de Campinas, SP, Brazil. The means of the observed $\left(H_{\mathrm{O}}\right)$ and expected $\left(H_{\mathrm{E}}\right)$ heterozygosities, breeding index $(f)$, and allelic richness in $P$. cuvieri populations are also shown.

The overall $F_{\mathrm{ST}}$ value indicated a genetic variation of $27.1 \%$ between the $P$. cuvieri populations. Pairwise $F_{\mathrm{ST}}$ values ranged from 0.076 between TO3 and BA9 and up to 0.428 between the MA2 and SP6 populations (Table 2).

STRUCTURE analysis revealed a $\triangle \mathrm{K}$ max of 56.31 and $\mathrm{K}=9$ (data not shown) and clustered the 10 P. cuvieri populations into 9 groups. As depicted in Figure 2, the groups are distinguished by colors. Population clustering probabilities are listed in Table 3 , and the letters A to I represent the clusters. Of 160 specimens, 91 (56.8\%) were assigned to a cluster with $\geq 0.90$ probability. In the SP5 and SP6 populations, 18 specimens of 91 (19.7\%) were grouped within the same cluster. Only the SP7 population had all 12 specimens $(100 \%)$ assigned to a single cluster. 
Table 2. $F_{\mathrm{ST}}$ pairwise comparisons between the ten Physalaemus cuvieri populations.

\begin{tabular}{|c|c|c|c|c|c|c|c|c|c|c|}
\hline Population & MA1 & MA2 & TO3 & MG4 & SP5 & SP6 & SP7 & MT8 & BA9 & RS10 \\
\hline MA1 & - & & & & & & & & & \\
\hline MA2 & 0.288 & - & & & & & & & & \\
\hline TO3 & 0.158 & 0.236 & - & & & & & & & \\
\hline MG4 & 0.278 & 0.323 & 0.193 & - & & & & & & \\
\hline SP5 & 0.310 & 0.350 & 0.227 & 0.193 & - & & & & & \\
\hline SP6 & 0.350 & 0.428 & 0.273 & 0.238 & 0.080 & - & & & & \\
\hline SP7 & 0.352 & 0.405 & 0.220 & 0.386 & 0.308 & 0.392 & - & & & \\
\hline MT8 & 0.289 & 0.347 & 0.115 & 0.329 & 0.298 & 0.405 & 0.143 & - & & \\
\hline BA9 & 0.263 & 0.299 & 0.076 & 0.284 & 0.287 & 0.366 & 0.239 & 0.092 & - & \\
\hline RS10 & 0.256 & 0.283 & 0.215 & 0.248 & 0.214 & 0.322 & 0.323 & 0.258 & 0.237 & - \\
\hline
\end{tabular}

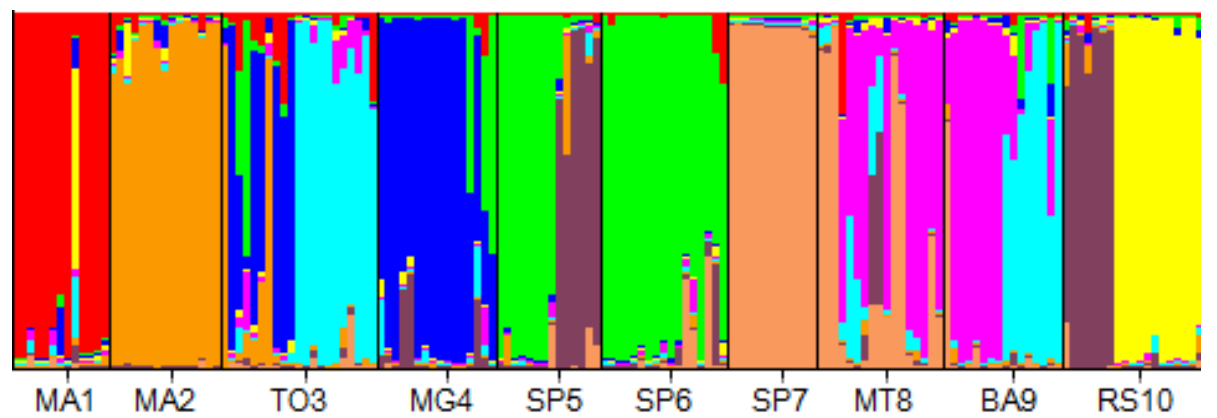

Figure 2. Graph of the STRUCTURE analysis for $\mathrm{K}=9$. Each vertical line represents a Physalaemus cuvieri specimen, and the color composition indicates the probability of the specimen belonging to each of the 9 clusters defined by the program.

Table 3. Results of the clustering analysis (STRUCTURE) for $\mathrm{K}=9$ (mean posterior probability for each population).

\begin{tabular}{|c|c|c|c|c|c|c|c|c|c|c|c|}
\hline \multirow[t]{2}{*}{ Population } & \multirow[t]{2}{*}{$\mathrm{N}$} & \multicolumn{9}{|c|}{ Inferred clusters } & \multirow[b]{2}{*}{$\mathrm{P}<0.90$} \\
\hline & & A & B & $\mathrm{C}$ & $\mathrm{D}$ & $\mathrm{E}$ & $\mathrm{F}$ & G & $\mathrm{H}$ & I & \\
\hline MA1 & 13 & $\mathbf{9} / 0.863$ & 0.007 & 0.023 & 0.048 & 0.013 & 0.021 & 0.008 & 0.007 & 0.010 & 4 \\
\hline MA2 & 15 & 0.022 & 0.005 & 0.016 & 0.017 & 0.007 & 0.007 & $10 / 0.916$ & 0.005 & 0.006 & 5 \\
\hline TO3 & 21 & 0.054 & 0.056 & $\mathbf{1} / 0.249$ & 0.010 & 0.041 & $3 / 0.454$ & 0.111 & 0.008 & 0.018 & 17 \\
\hline MG4 & 16 & 0.014 & 0.108 & $9 / 0.767$ & 0.012 & 0.011 & 0.027 & 0.006 & 0.051 & 0.005 & 7 \\
\hline SP5 & 14 & 0.006 & $6 / 0.551$ & 0.009 & 0.005 & 0.008 & 0.010 & 0.035 & $2 / 0.351$ & 0.026 & 6 \\
\hline SP6 & 17 & 0.024 & $12 / 0.863$ & 0.006 & 0.007 & 0.013 & 0.006 & 0.007 & 0.027 & 0.046 & 5 \\
\hline SP7 & 12 & 0.005 & 0.006 & 0.004 & 0.003 & 0.006 & 0.006 & 0.004 & 0.005 & $12 / 0.961$ & - \\
\hline MT8 & 17 & 0.022 & 0.005 & 0.009 & 0.011 & $1 / 0.468$ & 0.085 & 0.009 & 0.060 & 2/0.329 & 14 \\
\hline BA9 & 16 & 0.009 & 0.031 & 0.017 & 0.010 & $6 / 0.485$ & 3/0.374 & 0.012 & 0.007 & 0.056 & 7 \\
\hline RS10 & 19 & 0.008 & 0.008 & 0.008 & $\mathbf{1 0} / 0.596$ & 0.007 & 0.008 & 0.018 & $\mathbf{5} / 0.334$ & 0.013 & 4 \\
\hline
\end{tabular}

Numbers in bold represent the specimens assigned to one of the 9 clusters with a probability $\geq 0.90$. The last column shows specimens below the assignment of $0.90 . \mathrm{N}=$ total sample size.

\section{Mitochondrial DNA analysis}

The genetic distance analysis of the 10 P. cuvieri populations showed the smallest value (0.004) among SP7 to SP5 and SP6 and the largest value (0.077) between MT8 and TO3. Despite having been sampled from very distant locations (more than $2000 \mathrm{~km}$ ), seven populations (MG4, SP5, SP6, SP7, MT8, BA9, and RS10) displayed a genetic distance $<0.03$ between them. The population TO3 showed high genetic distance $(>0.03)$ when compared with all the other populations. High genetic distances were also noted between MA1 or MA2 
and the remaining populations (Table 4). The GenBank accession numbers are listed in Table 5. Two sequences from MA2 and one from SP6 are currently in submission (Lourenço LB, Targueta CP, Baldo D, Nascimento J, et al., unpublished data).

Table 4. Genetic distance determined from the mitochondrial DNA data between ten Physalaemus cuvieri populations.

\begin{tabular}{|c|c|c|c|c|c|c|c|c|c|c|c|c|c|c|}
\hline Population & MA1 & MA2 & TO3 & MG4 & SP5 & SP6 & SP7 & MT8 & BA9 & RS10 & OUT-1 & OUT-2 & OUT-3 & OUT-4 \\
\hline MA1 & & 587.19 & 673.75 & 1564.29 & 1769.00 & 1746.03 & 1798.00 & 1422.00 & 1399.00 & 2631.85 & - & - & - & - \\
\hline MA2 & 0.016 & & 992.89 & 1808.12 & 2028.26 & 2080.34 & 2098.46 & 1899.97 & 1316.18 & 2936.75 & - & - & - & - \\
\hline TO3 & 0.071 & 0.075 & & 903.44 & 1052.03 & 1045.33 & 1357.76 & 942.42 & 928.77 & 1956.25 & - & - & - & - \\
\hline MG4 & 0.062 & 0.067 & 0.076 & & 289.21 & 203.19 & 288.39 & 874.35 & 906.29 & 1033.52 & - & - & - & - \\
\hline SP5 & 0.061 & 0.066 & 0.075 & 0.013 & & 109.40 & 135.42 & 766.32 & 1188.18 & 905.08 & - & - & - & - \\
\hline SP6 & 0.063 & 0.067 & 0.076 & 0.015 & 0.005 & & 99.41 & 861.79 & 1103.55 & 943.96 & - & - & - & - \\
\hline SP7 & 0.063 & 0.067 & 0.075 & 0.014 & 0.004 & 0.004 & & 904.81 & 1163.67 & 878.43 & - & - & - & - \\
\hline MT8 & 0.063 & 0.067 & 0.077 & 0.017 & 0.013 & 0.015 & 0.013 & & 1560.70 & 1437.55 & - & - & - & - \\
\hline BA9 & 0.061 & 0.064 & 0.073 & 0.020 & 0.024 & 0.025 & 0.025 & 0.025 & & 1931.00 & - & - & - & - \\
\hline RS10 & 0.061 & 0.066 & 0.071 & 0.014 & 0.012 & 0.014 & 0.013 & 0.014 & 0.016 & & - & - & - & - \\
\hline OUT-1 & 0.171 & 0.170 & 0.177 & 0.179 & 0.179 & 0.179 & 0.179 & 0.175 & 0.179 & 0.178 & & - & - & - \\
\hline OUT-2 & 0.176 & 0.174 & 0.174 & 0.176 & 0.176 & 0.176 & 0.176 & 0.175 & 0.173 & 0.173 & 0.186 & & - & - \\
\hline OUT-3 & 0.179 & 0.178 & 0.180 & 0.176 & 0.174 & 0.175 & 0.175 & 0.173 & 0.174 & 0.173 & 0.126 & 0.181 & & - \\
\hline OUT-4 & 0.185 & 0.179 & 0.177 & 0.184 & 0.185 & 0.184 & 0.184 & 0.179 & 0.182 & 0.185 & 0.185 & 0.100 & 0.186 & \\
\hline
\end{tabular}

Outgroups are designated as: OUTG- $1=P$. nattereri; $2=P$. gracilis; $3=P$. signifer $; 4=P$. barrioi. The four outgroup samples are presented below diagonal. The geographic distances $(\mathrm{km})$ between the populations are presented above diagonal.

Table 5. GenBank accession numbers for all 28 16S sequences obtained from the Physalaemus cuvieri populations and the four outgroup samples.

\begin{tabular}{|c|c|c|}
\hline Population & Sequence & GenBank \\
\hline \multirow[t]{2}{*}{ MA1 } & 92.11_16S & HQ592376 \\
\hline & $92.09-16 \mathrm{~S}$ & HQ592375 \\
\hline \multirow[t]{3}{*}{ MA2 } & 92.17_-16S & In submission \\
\hline & 92.19_16S & In submission \\
\hline & $92.30^{-} 16 \mathrm{~S}$ & HQ592368 \\
\hline \multirow[t]{3}{*}{ TO3 } & $92.76^{-} 16 \mathrm{~S}$ & HQ592362 \\
\hline & 92.77_-16S & HQ592363 \\
\hline & $92.86 \_16 \mathrm{~S}$ & HQ592364 \\
\hline \multirow[t]{3}{*}{ MG4 } & 92.88_16S & HQ592365 \\
\hline & $92.89 \_16 \mathrm{~S}$ & HQ592366 \\
\hline & $92.90 \_16 \mathrm{~S}$ & HQ592367 \\
\hline \multirow[t]{3}{*}{ SP5 } & $92.97 \_16 \mathrm{~S}$ & HQ592369 \\
\hline & $92.99^{-} 16 \mathrm{~S}$ & HQ592370 \\
\hline & $92.10 \overline{0} 16 \mathrm{~S}$ & HQ592371 \\
\hline \multirow[t]{3}{*}{ SP6 } & $92.101 \_16 \mathrm{~S}$ & HQ592357 \\
\hline & $92.102 \_16 \mathrm{~S}$ & HQ592358 \\
\hline & $92.143 \_16 \mathrm{~S}$ & In submission \\
\hline \multirow[t]{3}{*}{ SP7 } & $92.64 \_\overline{1} 6 \mathrm{~S}$ & HQ592355 \\
\hline & $92.15 \overline{8} \_16 \mathrm{~S}$ & HQ592356 \\
\hline & $92.164 \_16 \mathrm{~S}$ & HQ592354 \\
\hline \multirow[t]{2}{*}{ MT8 } & $92.172 \_16 \mathrm{~S}$ & HQ592349 \\
\hline & $92.180^{-} 16 \mathrm{~S}$ & HQ592348 \\
\hline \multirow[t]{3}{*}{ BA9 } & $92.184 \_16 \mathrm{~S}$ & HQ592372 \\
\hline & $92.185 \_16 \mathrm{~S}$ & HQ592373 \\
\hline & $92.199 \_16 \mathrm{~S}$ & HQ592374 \\
\hline \multirow[t]{3}{*}{ RS10 } & $92.139 \_16 \mathrm{~S}$ & HQ592359 \\
\hline & $92.140-16 \mathrm{~S}$ & HQ592360 \\
\hline & $92.216-16 \mathrm{~S}$ & HQ592361 \\
\hline OUTG-1 & OUTG-1 & DQ337208.1 \\
\hline OUTG-2 & OUTG-2 & DQ283417.1 \\
\hline OUTG-3 & OUTG-3 & DQ337209.1 \\
\hline OUTG-4 & OUTG-4 & DQ337213.1 \\
\hline
\end{tabular}

Outgroup samples are designated as follows: OUTG-1 $=$ P. nattereri $; 2=$ P. gracilis; $3=$ P. signifer $; 4=$ P. barrioi . 


\section{DISCUSSION}

The $P$. cuvieri microsatellite markers in this study have been previously used to examine a number of alleles, null alleles, $H_{\mathrm{O}}$ and $H_{\mathrm{E}}$ and deviations from Hardy-Weinberg equilibrium (Conte et al., 2009). The dominance of the negative $f$ values described here is similar to that of previous studies on anurans. Negative inbreeding index values for $R$. temporaria populations have been found and indicate a favorable heterozygote selection (Schmeller and Merilä, 2007). In another study of Rana temporaria and Bufo bufo populations, the average $f$ values equaled zero, indicating an absence of inbreeding in these species (Seppä and Laurila, 1999). Hence, there was an apparent excess of heterozygotes, which was probably due to sampling. The lack of evidence of inbreeding in most of the populations sampled indicates that they are panmictic populations.

The private alleles identified in RS10 and SP5 may indicate that these two populations are more genetically isolated than the other populations examined. The RS10 population was separated into two subgroups that consisted of 7 specimens sampled in 2006 and 12 sampled in 2007. Although we found that the RS10 population formed an isolated group and suggested the presence of private alleles, other southern populations of the species were not sampled to confirm this result. A similar result was found when analyzing these populations together with other populations from the Physalaemus group using SSR data (Conte et al., 2011). However, the hypothesis that these specimens belong to a different species was not investigated here, and it certainly cannot be discarded.

In the present study, the high global $F_{\mathrm{ST}}$ value $(0.27)$ indicated high levels of genetic differentiation between the $P$. cuvieri populations examined. This finding is supported by several reports that have assessed the genetic structure in anuran species, including the following: Driscoll (1998a), studying Geocrinia alba and G. vitellina, and Driscoll (1998b), studying Geocrinia lutea and Geocrinia rosea, with both studies using allozymes; and Barber (1999), studying Hyla arenicolor using mitochondrial DNA, and Kraaijeveld-Smit et al. (2005), studying Alytes muletensis using microsatellite data.

Most of the $F_{\text {ST }}$ pairwise comparisons in this study indicated relatively high differentiation between the populations, since 42 of the pairwise comparisons were significantly different from zero. This range of pairwise $F_{\mathrm{ST}}$ values is similar to the range observed in other studies that have been performed in South and Central America. In Amazonian frogs, a mean pairwise $F_{\mathrm{ST}}=0.280$ has been found, indicating a strong, positive relationship between genetic divergence and differences between populations of $P$. petersi (Funk et al., 2009). Studies of two species from Central America, Dendropsophus ebraccatus and Agalychnis callidryas, showed that pairwise $F_{\mathrm{ST}}$ comparisons were significant in most populations, indicating restricted gene flow even between the populations within the regions of Costa Rica and Panama (Robertson et al., 2009).

To our knowledge, there is no other genetic study of $P$. cuvieri populations with which to compare these results. However, the $F_{\mathrm{ST}}$ data derived from other anuran species are in agreement with the data described here. The majority of previous studies that have investigated the genetic structure of anuran populations have addressed populations that were up to a few kilometers apart. On a larger geographic scale, the genetic differentiation between $P$. cuvieri populations has frequently been high. Our 10 polymorphic microsatellite loci showed genetic structuring of the natural $P$. cuvieri populations from regions of Brazil that were separated 
from each other by a distance of $100 \mathrm{~km}\left(F_{\mathrm{ST}}=0.397\right)$ to $2900 \mathrm{~km}\left(F_{\mathrm{ST}}=0.283\right)$.

The 10 P. cuvieri populations were clustered into nine groups. The SP5 and SP6 populations (109.40 km apart) were grouped together in the STRUCTURE analysis. However, although SP7 was located close to SP6 (99.4 km apart), they were distinguished from each other and from the remaining populations. A similar distinction occurred in the RS10 population, and the TO3 population was also divided into two sets of specimens. The TO3 population consisted of 10 specimens that were captured in an open pasture area in 2004 and 11 that were captured in a forest in 2007. The sampling areas for TO3 were $50 \mathrm{~m}$ apart from each other. The $10 \mathrm{TO} 3$ specimens captured in 2004 were grouped with MG4, and the 11 specimens captured in 2007 clustered together with individuals from BA9, indicating that these specimens share similar alleles.

The genetic distances determined from the mitochondrial DNA data revealed a value $>0.03 \%$ among MA1/MA2, TO3 and among the remaining populations. A threshold value of approximately 0.03 appears to be appropriate to distinguish between intra- and interspecific divergence between neotropical anurans (Fouquet et al., 2007a). Amphibians are often characterized by high levels of genetic differentiation. Intraspecific pairwise divergence of the mitochondrial $12 \mathrm{~S}$ and $16 \mathrm{~S}$ genes has been found to extend up to almost $6 \%$ (Vences et al., 2005). In most comparisons between conspecific populations, the values are lower. Divergences of approximately 4 to $5 \%$ usually indicate distinct species (Fouquet et al., 2007b). Defining a new species based on the genetic distances found in a single DNA fragment is problematic (Veith, 1996). However, above a certain threshold, the distance found could be used as an indicator for identifying candidate species (Fouquet et al., 2007a).

For several species, studies that have captured and recaptured animals have shown that neighboring amphibian populations can interact through migration and gene flow (Berven and Grudzien, 1990). However, some amphibians exhibit strong fidelity to their habitats and have low dispersive capabilities (Funk et al., 2005). Such behavior can contribute to the restriction of gene exchange between amphibian populations (Newman and Squire, 2001; Burns et al., 2004).

Several studies have shown that amphibians are highly philopatric (Berven and Grudzien, 1990; Seppä and Laurila, 1999; Manier and Arnold, 2006), and some amphibian populations tend to become isolated (Shaffer et al., 2000). Consequently, amphibians are highly vulnerable to environmental degradation, which can lead to a reduction in their population size (Ficetola and De Bernardi, 2004). Small and isolated populations lose genetic variability (Johansson et al., 2007), and increased interpopulation distances promote relative isolation among local populations (Rowe et al., 2000).

The data described in the present study reveal the high fidelity of the $P$. cuvieri populations to their breeding pond based on the geographic scales used. This finding suggests that $P$. cuvieri is strongly philopatric and has low vagility. The majority of the previous studies on the genetic structure of anuran populations have addressed populations that were a few kilometers apart. On a larger geographic scale, high levels of genetic differentiation between $P$. cuvieri populations have been frequently observed. The 10 polymorphic microsatellite loci investigated here showed genetic structuring within the natural populations of $P$. cuvieri that were isolated from regions of Brazil and were separated by distances ranging from $99.41 \mathrm{~km}$ $\left(F_{\mathrm{ST}}=0.615\right)$ to $2936 \mathrm{~km}\left(F_{\mathrm{ST}}=0.552\right)$.

In addition to revealing interpopulation genetic differentiation between the populations tested, the microsatellite analysis revealed important variation within populations. These results are in agreement with previously published studies that have demonstrated morpho- 
logical and cytogenetic polymorphisms within species at the inter- and intrapopulational level. Physalaemus cuvieri species may represent a complex of subspecies or species. This report confirms the need for more detailed molecular studies to better understand the variations that we found here.

\section{ACKNOWLEDGMENTS}

Research supported by Fundação de Amparo à Pesquisa do Estado de São Paulo (FAPESP - Grant \#06/59697-7, awarded to S.M.R. Pimentel) and Coordenação de Aperfeiçoamento de Pessoal de Nível Superior (CAPES - graduate scholarship awarded to M. Conte and PROEX grant to BCE graduate course). The authors thank Carmen S. Busin, Sérgio Siqueira Júnior, Maria Lúcia Del Grande, Denise C. Rossa-Feres and Gilda V. Andrade for access to the frog specimens.

\section{REFERENCES}

Barber PH (1999). Patterns of gene flow and population genetic structure in the canyon treefrog, Hyla arenicolor (Cope). Mol. Ecol. 8: 563-576.

Barreto L and Andrade GV (1995). Aspects of the reproductive biology of Physalaemus cuvieri (Anura: Leptodactylidae) in northeastern Brazil. Amphibia-Reptilia 16: 67-76.

Barrio A (1965). El gênero Physalaemus (Anura, Leptodactylidae) en la Argentina. Physis 25: 421-448.

Berven KA and Grudzien TA (1990). Dispersal in the Wood Frog (Rana sylvatica): Implications for genetic population structure. Evolution 44: 2047-2056.

Burns EL, Eldridge MD and Houlden BA (2004). Microsatellite variation and population structure in a declining Australian Hylid Litoria aurea. Mol. Ecol. 13: 1745-1757.

Conte M, Cançado LJ, Laborda PR and Zucchi MI (2009). Isolation and characterization of polymorphic microsatellites for the natural populations of barker frog Physalaemus cuvieri. Conserv. Genet. 10: 1849-1852.

Conte M, Zucchi MI, Andrade GV, Souza AP, et al. (2011). Study of closely related species within the Physalaemus cuvieri group (Anura): contribution of microsatellite markers. Genet. Mol. Res. 10: 1434-1444.

Creste S, Tulmann NA and Figueira A (2001). Detection of single sequence repeat polymorphisms in denaturing polyacrylamide sequencing gels by silver staining. Plant Mol. Biol. Rep. 19: 299-306.

Driscoll DA (1998a). Genetic structure, metapopulation processes and evolution influence the conservation strategies for two endangered frog species. Biol. Conserv. 83: 43-54.

Driscoll DA (1998b). Genetic structure of the frog Geocrinia lutea and Geocrinia rosea reflects extreme population divergence and range changes, not dispersal barriers. Evolution 52: 1147-1157.

Ersts PJ (2007). Geographic Distance Matrix Generator (version 1.2.3) American Museum of Natural History, Center for Biodiversity and Conservation. Available at [http://biodiversityinformatics.amnh.org/open_source/gdmg]. Accessed October 8, 2011.

Evanno G, Regnaut S and Goudet J (2005). Detecting the number of clusters of individuals using the software Structure: a simulation study. Mol. Ecol. 14: 2611-2620.

Ficetola GF and De Bernardi F (2004). Amphibians in a human-dominated landscape: the community structure is related to habitat features and isolation. Biol. Conserv. 119: 219-230.

Fouquet A, Gilles A, Vences M, Marty C, et al. (2007a). Underestimation of species richness in Neotropical frogs revealed by mtDNA analyses. PLoS One 2: e1109.

Fouquet A, Vences M, Salducci MD, Meyer A, et al. (2007b). Revealing cryptic diversity using molecular phylogenetics and phylogeography in frogs of the Scinax ruber and Rhinella margaritifera species groups. Mol. Phylogenet. Evol. 43: 567-582.

Frost DR (2013). Amphibians Species of the World: An Online Reference. Version 5.6 (January 9, 2011). Electronic Database Available at [http://research.amnh.org/vz/herpetology/amphibia/]. American Museum of Natural History, New York.

Frost DR, Grant T, Faivovich J, Bain R, et al. (2006). The Amphibian Tree of Life. Bulletin American Museum of Natural History, No. 297. Research Library, New York. 
Funk WC, Blouin MS, Corn PS, Maxell BA, et al. (2005). Population structure of Columbia spotted frogs (Rana luteiventris) is strongly affected by the landscape. Mol. Ecol. 14: 483-496.

Funk WC, Cannatella DC and Ryan MJ (2009). Genetic divergence is more tightly related to call variation than landscape features in the Amazonian frogs Physalaemus petersi and P. freibergi. J. Evol. Biol. 22: 1839-1853.

Global Amphibian Assessment (2009). 2009 IUCN / Species Survival Commission / CI / CABS / Nature Service. Available at [http://www.globalamphibians.org]. Accessed May 10, 2009.

Goebel AM, Donnelly JM and Atz ME (1999). PCR primers and amplification methods for 12S ribosomal DNA, the control region, cytochrome oxidase I, and cytochrome $b$ in bufonids and other frogs, and an overview of PCR primers which have amplified DNA in amphibians successfully. Mol. Phylogenet. Evol. 11: 163-199.

Goudet J (1995). FSTAT (VERSION 1.2): A Computer Program To Calculate F-Statistics. J. Hered. 86: 485-486.

Johansson M, Primmer CR and Merila J (2007). Does habitat fragmentation reduce fitness and adaptability? A case study of the common frog (Rana temporaria). Mol. Ecol. 16: 2693-2700.

Kraaijeveld-Smit FJ, Beebee TJ, Griffiths RA, Moore RD, et al. (2005). Low gene flow but high genetic diversity in the threatened Mallorcan midwife toad Alytes muletensis. Mol. Ecol. 14: 3307-3315.

Lewis PO and Zaykin D (2000). Genetic data analysis: computer program for the analysis of allelic data. Version 1.0 (d15). Free program distributed by authors over the Internet from the GDA. Available at [http://alleyn.eeb.uconn.edu/gda/2000].

Manier MK and Arnold SJ (2006). Ecological correlates of population genetic structure: a comparative approach using a vertebrate metacommunity. Proc. Biol. Sci. 273: 3001-3009.

Martins VG and Bacci Jr M (2001). Métodos Moleculares Para o Estudo do DNA I - Extração e Amplificação de DNA: Protocolos. Centro de Estudos de Insetos Sociais, UNESP/Rio Claro.

Nascimento LB, Caramaschi U and Cruz CAG (2005). Taxonomic review of the species groups of the genus Physalaemus Fitzinger, 1826 with revalidation of the genera Engystomops Jiménez-de-La-Espada, 1872 and Eupemphix Steindachner, 1863 (Amphibia, Anura, Leptodactylidae). Arq. Mus. Nac. Rio de Janeiro 63: 297-320.

Newman RA and Squire T (2001). Microsatellite variation and fine-scale population structure in the wood frog (Rana sylvatica). Mol. Ecol. 10: 1087-1100.

Pritchard JK, Stephens M and Donnelly P (2000). Inference of population structure using multilocus genotype data. Genetics 155: 945-959.

Pyron RA and Wiens JJ (2011). A large-scale phylogeny of Amphibia including over 2800 species, and a revised classification of extant frogs, salamanders, and caecilians. Mol. Phylogenet. Evol. 61: 543-583.

Quinderé YRSD, Tomatis C, Baldo D and Lourenço LB (2009). Polytypic and polymorphic cytogenetic variations in the widespread anuran Physalaemus cuvieri (Anura, Leiuperidae) with emphasis on nucleolar organizing regions. Biol. Res. 42: 79-92.

Robertson JM, Duryea MC and Zamudio KR (2009). Discordant patterns of evolutionary differentiation in two Neotropical treefrogs. Mol. Ecol. 18: 1375-1395.

Ron SR, Santos JC and Cannatella DC (2006). Phylogeny of the tungara frog genus Engystomops (= Physalaemus pustulosus species group; Anura: Leptodactylidae). Mol. Phylogenet. Evol. 39: 392-403.

Rowe G, Beebee TJC and Burke T (2000). A microsatellite analysis of natterjack toad, Bufo calamita, metapopulations. Oikos 88: 641-651.

Schmeller DS and Merilä J (2007). Demographic and genetic estimates of effective population and breeding size in the amphibian Rana temporaria. Conserv. Biol. 21: 142-151.

Seppä P and Laurila A (1999). Genetic structure of island populations of the anurans Rana temporaria and Bufo bufo. Heredity 82: 309-317.

Shaffer HB, Fellers GM, Magee A and Voss SR (2000). The genetics of amphibian declines: population substructure and molecular differentiation in the yosemite toad, Bufo canorus (Anura, Bufonidae) based on single-strand conformation polymorphism analysis (SSCP) and mitochondrial DNA sequence data. Mol. Ecol. 9: 245-257.

Silva APZ, Haddad CFB and Kasahara S (1999). Nucleolus organizer regions in Physalaemus cuvieri (Anura, Leptodactylidae), with evidence of a unique case of Ag-NOR variability. Hereditas 131: 135-141.

Tamura K, Dudley J, Nei M and Kumar S (2007). MEGA4: Molecular Evolutionary Genetics Analysis (MEGA) software version 4.0. Mol. Biol. Evol. 24: 1596-1599.

Telles MP, Bastos RP, Soares TN, Resende LV, et al. (2006). RAPD variation and population genetic structure of Physalaemus cuvieri (Anura: Leptodactylidae) in Central Brazil. Genetica 128: 323-332.

Veith M (1996). Molecular markers and species delimitation: examples from the European batrachofauna. AmphibiaReptilia 7: 303-314.

Vences M, Thomas M, van der Meijden A, Chiari Y, et al. (2005). Comparative performance of the 16S rRNA gene in DNA barcoding of amphibians. Front. Zool. 2: 5.

Wright S (1951). The genetical structure of populations. Ann. Eugenics 15: 321-354. 